\title{
REDUCTION OF COCKROACH DENSITY AND SPREADING IN BENHA UNIVERSITY HOSPITALS (EGYPT) IN THE YEAR 2019 COMPARED WITH THE YEAR 2014
}

\author{
Mohamed M. Baz ${ }^{*}$; Maysa M. Hegazy ${ }^{1,2}$ \\ ${ }^{\mathbf{1}}$ Entomology Department, Faculty of Science, Benha University, Qalyubiya, Egypt \\ ${ }^{2}$ Biology Department, Faculty of Science, Jazan University, Jazan, Saudi Arabia
}

\author{
Article History: \\ Received: 23 December 2020 \\ Revised: 6 January 2021 \\ Accepted: 7 January 2021 \\ Published Online: \\ 11 January 2021 \\ Keywords: \\ Cockroach density \\ Cockroach spp. \\ Temperature \\ Relative humidity \\ University hospitals

\section{*Correspondence:} \\ Mohamed Baz \\ Entomology Department \\ Faculty of Science \\ Benha University \\ Qalyubiya, Egypt \\ E-mail: \\ mohamed.albaz@fsc.bu.edu.eg
}

\begin{abstract}
Cockroaches cause a public health-problem associated with human wastes and disease pathogens. In the present study, the distribution of cockroach populations was evaluated in different places at Benha University Hospitals in the years 2014 and 2019 by using sticky paper traps. The German cockroach "Blattella germanica" was the most prevalence species captured $(84.4 \%)$, followed by the American cockroach "Periplaneta americana (14.6\%)", and the brown cockroach "Periplaneta brunnea (0.99\%)". The German and American cockroaches were found in all areas of the hospitals, while the brown cockroaches were only caught in the kitchen, outpatient clinics, and medical supply storages of the hospitals. The population density of cockroaches in the hospitals recorded a higher number of cockroaches $/ 10 \mathrm{~m}^{2}(94.7 \pm 11.1)$ and the infestation rate $(30.9 \%)$ in kitchens compared to other places in 2014; while the highest number of cockroaches/10 $\mathrm{m}^{2}$ (21.6 \pm 0.2$)$ and the infestation rate $(43.0 \%)$ were recorded in outpatient clinics compared to other places in 2019. The results also showed a very significant correlation between the cockroach population density and the temperature $(\mathrm{R}=0.897$, $P=0.006)$; but it was inversely correlated with relative humidity $(\mathrm{R}=-0.433, P=0.332)$ in 2014; while in 2019 a non-significant positive correlation was observed between population density and both the temperature and the relative humidity. It was clear that the cockroach population density was reduced in 2019 compared to $2014(\mathrm{~F}=54.17, P<0.01)$, possibly due to application of various mechanisms to control cockroaches besides raising hygiene level in the hospitals.
\end{abstract}

\section{INTRODUCTION}

Cockroaches are common and serious pest insects that inhabit many public places such as hospitals, houses, schools, manufacturing sites $^{[1,2]}$. The presence of cockroaches in the human dwelling is not lovable, because they can spread disease by contaminating human food with many important pathogenic microorganisms: bacteria, viruses, protozoa, and fungi ${ }^{[3-5]}$.

The German and American cockroaches are pests that threaten human health because 
of their filthy habits, bad smell, and nature of body composition. Also, they are secreting an oily liquid that has an offensive and sickening odor that may desolate food $^{[6]}$. In addition to the seriousness and importance of cockroaches in transmitting the disease, it acting as potential transmitters for many dangerous microorganisms ${ }^{[7]}$, and they can produce scales or odor that cause allergic symptoms and childhood asthma ${ }^{[8]}$. Cockroaches are naturally able to transmit more than forty bacterial disease species and they can be infected by some other laboratory bacteria ${ }^{[9]}$. Cockroaches isolated from hospitals and residential areas carry important pathological microorganisms ${ }^{[10]}$.

The biodiversity of the cockroach population varies according to climate, especially in warm and humid places, where cockroaches are found on almost all continents and in almost all types of habitats ${ }^{[11]}$. The German cockroach "Blattella germanica L. (Dictyoptera: Blattellidae)" and the Americana cockroach "Periplaneta americana L. (Blattodea: Blattidae)" have inhabited the hospitals and houses with a high infestation ${ }^{[4,12]}$. In hospitals and other human settlements, cockroaches feed on a variety of animal products including meat, starchy food, sweets, grease, and other unprotected materials $^{[3,13]}$. Blattella germanica is the most encountered of the hospitals' pests $^{[5,14-15]}$. Among cockroaches caught in hospitals, Blattella germanica was the predominant species. This is maybe due to its larger egg ratio per capsule and shorter developmental period than other species $^{[16]}$.

Recently, several studies have been carried out to determine the population dynamic of cockroaches in some hospitals and apartments in Egypt $^{[15,17]}$, Sudan ${ }^{[4]}$, Turkey $^{[2,18]}$ and Korea ${ }^{[16,19]}$ and other countries to enhance the understanding of biological and ecological aspects for developing and design appropriate strategies for cockroach control according to the place nature. The information about the cockroach population dynamic in University hospitals in Egypt is rather scarce. Therefore, the present study was carried out to determine cockroach abundance, distribution, infestation rate, and the influence of some parameters such as humidity, and temperature on the cockroach population dynamics in Benha University Hospitals.

\section{MATERIAL AND METHODS Experimental site}

This study was carried out in Benha University Hospitals in 2014 and 2019 during the cold season (November-April) and the warm season (May-October). Benha University Hospitals are located $55 \mathrm{~km}$ north of Cairo, adjacent to Damietta Nile branch, and they are affiliated with Benha Medical College. Benha University Hospitals are consisting of the internal medicine hospital, surgery hospital, ophthalmology hospital, and emergency hospital. There are 19 clinical departments with other specialist units, whereas the medical and therapeutic services are presented to all the residents of Benha City and the neighboring places where the city receives about 1500 visitors daily.

\section{Insect collection}

Cockroaches were sampled from different sites in three sections: internal medicine, surgery, and ophthalmology buildings at Benha University Hospitals using sticky traps. To determine cockroach population densities, species composition, 20 places (six patient rooms or wards, four nurse rooms, three outpatient clinics rooms, two worker rooms, two medical supply storage, two care units, and one kitchen) in hospitals were examined. The number of sticky traps used for cockroach sampling was two or five depending on the area of the study sites (one trap per $5 \mathrm{~m}^{2}$ ). Those traps were placed where cockroaches were likely to be found; under patient beds or nurse beds, furniture, behind refrigerators and medical cupboards, medical storage, and corners of rooms. The sticky traps were left in these places for one week/month and they were transported to the laboratory for identification with a stander 
taxonomy key ${ }^{[20]}$. All the specimens were examined to determine cockroach species, and cockroaches were counted by life stages (nymph and adult). The nymph stage was determined according to the last segment, as stated before ${ }^{[21]}$.

\section{Weather Data Collection}

The humidity and temperature were measured weekly in the sampled sites by the Landtek HT-6290 humidity temperature device (Bay Shore, NY, USA).

\section{Statistical analysis}

The statistical analysis was carried out by ANOVA under the significance level of 0.05 for the whole results using statistical package of social sciences (SPSS) statistics software for windows, version 22 (IBM corp., Armonk, NY, USA), in addition to the correlation between the humidity/temperature and the cockroach population. Multiple comparisons were carried out applying the Least Significant Difference (LSD) post-hoc test.

\section{RESULTS}

Surveying of cockroaches were carried out in some location inside three sections of Benha University Hospitals. A total of
12220 cockroaches was collected during the study period in 20 different places with an average of 289.9 and 42.8 cockroaches $/ 10 \mathrm{~m}^{2}$ in 2014 and 2019, respectively (Tables 1 and 2).

Data presented in Tables "1 and 2" showed that cockroach population density was high in the kitchen $(94.7 \pm 11.1$ individuals $/ 10 \mathrm{~m}^{2}$ ), followed by worker rooms, nurse rooms, patient rooms, outpatient clinics, and medical supply storages, where the population density of cockroaches was low in care units $\left(9.5 \pm 1.5\right.$ individuals $\left./ 10 \mathrm{~m}^{2}\right)$ during 2014 . In 2019, the cockroach population density was high in outpatient clinics $(21.6 \pm 0.2$ individuals $/ 10 \mathrm{~m}^{2}$ ); followed by worker rooms, nurse rooms, kitchen, medical supply storages, patient rooms; and they were low in the care units $(1.6 \pm 0.4$ individuals $/ 10 \mathrm{~m}^{2}$ ) during 2019. There were significant differences among the numbers of cockroaches collected in recorded locations $(P<0.05)$ during the period time. Also, data showed that the highest infestation rate of cockroach population was in kitchens $(30.9 \%)$ and outpatient clinics $(43.0 \%)$ during the study period 2014 and 2019, respectively (Tables 1 and 2).

Table 1: The population density and infestation rate of Blattella germanica, Periplaneta americana, and Periplaneta brunnea in different sites of the hospitals (2014).

\begin{tabular}{lccccc}
\hline Places (No.) & $\mathrm{N}$ & $\mathrm{n}$ & $\begin{array}{c}\text { Individuals/10 } \mathrm{m}^{2 *} \\
(\text { Mean } \pm \mathrm{SE})\end{array}$ & Nymphs (\%) & Infestation Rates (\%) \\
\hline Kitchen (1) & 8 & 3031 & $94.7 \pm 11.1^{\mathrm{a}}$ & 83.9 & 30.9 \\
Patient rooms (6) & 32 & 1504 & $23.5 \pm 2.6^{\mathrm{d}}$ & 56.6 & 15.3 \\
Worker rooms (2) & 22 & 1695 & $77.0 \pm 7.1^{\mathrm{b}}$ & 57.8 & 17.3 \\
Nurse rooms (4) & 26 & 1257 & $48.3 \pm 7.5^{\mathrm{c}}$ & 44.4 & 12.8 \\
Outpatient clinics (3) & 12 & 1651 & $22.9 \pm 2.5^{\mathrm{d}}$ & 51.9 & 16.8 \\
Care units (2) & 12 & 227 & $9.5 \pm 1.5^{\mathrm{e}}$ & 28.2 & 2.3 \\
Medical supply storages (2) & 16 & 446 & $13.9 \pm 1.8^{\mathrm{d}}$ & 53.7 & 4.5 \\
Total (20) & 128 & 9811 & $289.9 \pm 34.3$ & & 100.0 \\
\hline
\end{tabular}

$\mathrm{N}$ : Number of positive visiting/place/year; $\mathrm{n}$ : total number of cockroaches; SE: standard error;

$*$ : Cockroach density. Infestation rates $(\%)=[\mathrm{n}$ in each place $/ \mathrm{n}$ in the total places $] \times 100$. Values with different superscript letters within the same column were significantly different $(P<0.05)$. 
Table 2: The population density and infestation rate of Blattella germanica, Periplaneta americana, and Periplaneta brunnea in different sites of the hospitals (2019).

\begin{tabular}{lccccc}
\hline Places (No.) & $\mathrm{N}$ & $\mathrm{n}$ & $\begin{array}{c}\text { Individuals/10 } \mathrm{m}^{2 *} \\
(\text { Mean } \pm \mathrm{SE})\end{array}$ & Nymphs (\%) & Infestation Rates (\%) \\
\hline Kitchen (1) & 10 & 214 & $3.6 \pm 0.6^{\mathrm{b} * *}$ & 67.4 & 8.9 \\
Patient rooms (6) & 36 & 164 & $2.3 \pm 0.4^{\mathrm{b}}$ & 49.1 & 6.8 \\
Worker rooms (2) & 28 & 519 & $6.2 \pm 0.9^{\mathrm{b}}$ & 65.1 & 21.5 \\
Nurse rooms (4) & 16 & 288 & $5.1 \pm 0.7^{\mathrm{b}}$ & 44.2 & 12.0 \\
Outpatient clinics (3) & 12 & 1037 & $21.6 \pm 0.2^{\mathrm{a}}$ & 77.7 & 43.0 \\
Care units (2) & 16 & 50 & $1.6 \pm 0.4^{\mathrm{b}}$ & 16.0 & 2.1 \\
Medical supply storages (2) & 14 & 137 & $2.4 \pm 0.3^{\mathrm{b}}$ & 33.1 & 5.7 \\
Total (20) & 132 & 2409 & $42.8 \pm 3.5$ & & 100.0 \\
\hline
\end{tabular}

$\mathrm{N}$ : Number of positive visiting/place/year; $n$ : total number of cockroaches; SE: standard error; *: Cockroach density. Infestation rates $(\%)=[\mathrm{n}$ in each place/n in the total places] $\times 100$. Values with different superscript letters within the same column were significantly different $(P<0.05)$.

Three cockroach species were captured from Benha University Hospitals, Blattella germanica (10314) that are the most common species in all sites of hospitals during the study period when compared to other species such as $P$. americana (1785) and $P$. brunnea (121) that are lowest common in all sites of hospitals (Table 3 ). As well as, the infestation rate was high in Blattella germanica (84.4\%) followed by $P$. americana $(14.6 \%)$ and $P$. brunnea $(0.99 \%)$. Data presented in Table " 3 " showed that Blattella germanica was the most common species captured in the kitchen of the hospital (2857), and $P$. americana was captured with larger density in outpatient clinics (884) than other sites in the hospital. P. brunnea were only captured in the kitchen, outpatient clinics, and medical supply storages of hospitals. The number of cockroaches $/ 10 \mathrm{~m}^{2}$ in the recorded places showed very significant differences (one-way ANOVA: $\mathrm{F}=23.9, P<0.001$ and $\mathrm{F}=14.12, P<0.001)$ in 2014 and 2019 , respectively.

Table 3: Total number of cockroach populations captured from the hospitals during 2014 and 2019.

\begin{tabular}{lccc}
\hline \multirow{2}{*}{ Places } & \multicolumn{3}{c}{ Total number of cockroach species (Infestation rates \%) } \\
\cline { 2 - 4 } & Blattella germanica & Periplaneta americana & Periplaneta brunnea \\
\hline Kitchen & $2857(23.4)$ & $346(2.8)$ & $42(0.34)$ \\
Patient rooms & $1511(12.4)$ & $157(1.3)$ & $0(0.00)$ \\
Worker rooms & $1999(16.4)$ & $215(1.8)$ & $0(0.00)$ \\
Nurse rooms & $1423(11.6)$ & $122(1.0)$ & $0(0.00)$ \\
Outpatient clinics & $1742(14.3)$ & $884(7.2)$ & $62(0.51)$ \\
Care units & $270(2.2)$ & $7(0.1)$ & $0(0.00)$ \\
Medical supply storages & $512(4.2)$ & $54(0.4)$ & $17(0.14)$ \\
Total & $10314(84.4)$ & $1785(14.6)$ & $121(0.99)$ \\
\hline
\end{tabular}

Infestation rates $(\%)=$ [number of cockroach species in each place or in total places/12220] $\times$ 100 
There was a positive correlation between temperature and cockroach population density $(\mathrm{R}=0.897, P=0.006)$, but it was inversely with relative humidity $(\mathrm{R}=-0.433, P=0.332)$ in 2014 , while in 2019 a non-significant positive correlation was observed between population density and both temperature and relative humidity $(\mathrm{R}=0.702, P=0.079$ and $\mathrm{R}=0.491$, $P=0.263$, respectively) as shown in Table "4".

Table 4: The average temperature $(\mathrm{T})$ and relative humidity $(\mathrm{RH})$ in the different places in the hospital.

\begin{tabular}{lccccc}
\hline \multirow{2}{*}{ Places } & \multicolumn{2}{c}{2014} & & \multicolumn{2}{c}{2019} \\
\cline { 2 - 3 } \cline { 5 - 6 } & $\mathrm{T}\left({ }^{\circ} \mathrm{C}\right)$ & $\mathrm{RH}(\%)$ & & $\mathrm{T}\left({ }^{\circ} \mathrm{C}\right)$ & $\mathrm{RH}(\%)$ \\
\hline Kitchen & 26.6 & 74.3 & & 23.4 & 72.0 \\
Patient rooms & 24.1 & 67.4 & & 22.0 & 68.0 \\
Worker rooms & 24.5 & 66.5 & & 25.2 & 72.0 \\
Nurse rooms & 24.2 & 65.6 & & 23.0 & 81.0 \\
Outpatient clinics & 22.6 & 77.0 & & 21.6 & 78.0 \\
Care units & 22.3 & 78.0 & & 21.5 & 72.0 \\
Medical supply storages & 22.0 & 71.0 & & 22.8 & 66.0 \\
\hline Correlation coefficient $(\mathrm{R})$ & 0.897 & -0.433 & & 0.702 & 0.491 \\
$X^{2}$ & 0.006 & 0.332 & & 0.079 & 0.263 \\
\hline
\end{tabular}

\section{DISCUSSION}

Cockroaches represent a state of nuisance and disgust, in addition to transmitting diseases, they inhabit various public places. The present study was conducted to find out the normal presence of cockroaches in Benha University Hospitals; where, the results showed that three types of cockroaches were captured from different places in hospitals during 2014 and 2019. They are classified into three species, among them the German cockroach, Blattella germanica (Linnaeus), is the most prevalence in all hospital departments and followed by $P$. americana (Linnaeus), while the $P$. brunnea (Burmeister) cockroach was the least widespread in recorded place and maybe it was not previously detected from these places.

Our finding is in agreement with Memona et $a l^{[5]}$ who reported that the residential area and hospitals were severely infested with Blattella germanica, followed by $P$. americana, which spread according to the availability of food sources and climatic conditions. Many researchers mentioned that the American cockroach " $P$. americana" is the most prevalent in all places, especially in kitchens, homes, and places of food processing; while there are other researchers confirmed that the German cockroach "Blattella germanica" is the most prevalent in those places, as well as recorded in some location of hospital ${ }^{[15,17,21]}$. The present study confirmed the findings of previous studies regarding the prevalence and spread of the German cockroach compared with the American cockroach ${ }^{[15,22]}$ and the brown cockroach especially in hospitals.

The American and German cockroaches were captured in kitchens and patient rooms of the Korean hospitals, while the highest rates of the German cockroaches were recorded in kitchens ${ }^{[16]}$. The highest cockroach population density was in kitchen and Blattella germanica and P. americana was the most dominant species captured in Egyptian hospitals ${ }^{[15]}$. It is a common knowledge that in some places such as restaurants, homes, and hospitals cockroaches feed on a variety of animal products, including lard, meat, starchy foods, sweets, and other materials ${ }^{[2]}$. Blattella germanica, $P$. americana, Blatta orientalis, and the 
brown-banded "P. brunnea" cockroaches were the most common worldwide cockroaches $^{[23]}$.

Climatic factors affect the spread of cockroaches, but the temperature and relative humidity play a vital role in the prevalence process, so most types of cockroaches spread in tropical regions and only a few of them in temperate regions ${ }^{[24,25]}$ In the current study, the temperature affected the number of cockroaches that were caught in the selected places, while the relative humidity was not significant. There were a positive correlation between daily temperature and hunting in outdoor gatherings ${ }^{[26]}$. In unheated structures, all American cockroaches died in air temperatures of $0.0{ }^{\circ} \mathrm{C}$ despite reaching sawdust, and $40 \%$ of cockroaches died within 72 hours at $10{ }^{\circ} \mathrm{C}^{[27]}$.

Hospitals are a healthcare place providing treatment for patients by medical staff, specialized nursing, and medical equipment. Therefore, the hospital environment must be kept clean and under control from medical insects, because of its important role in the transmission of diseases. Several studies have been conducted on the importance and seriousness of cockroaches in hospitals ${ }^{[14,28]}$, since cockroaches carry many of pathogens to human nature and they are known to transmit pathogens such as cholera, diphtheria, pneumonia, tetanus, and tuberculosis $^{[29]}$. The excrement cockroaches, as well as their external contaminated body, can also infect food, hospital's equipment, and human homes ${ }^{[12]}$. The occurrence of cockroaches in hospitals will lead to the inevitable spread of diseases between patients. Therefore, it is important to give some stress to study these pests in the Egyptian hospitals especially that they are very abundant in hospitals such as "Blattella germanica", as noticed during the present study. Application of insecticides is considered an effective way to manage pest infestation, but the unwise use of broadspectrum synthetic insecticides may be led to the development of resistance in the treated population. Some studies mentioned that cockroach resistance has been reported to some compounds such as bendiocarb, cypermethrin, permethrin, propoxur, and chlorpyrifos $^{[30,31]}$. So, a strategy for cockroach control using available and safer biological or chemical agents (selective insecticide alone or combination) with environmental management is urgent required.

In conclusion, the present study showed a relative success and a remarkable decrease in the density of cockroaches in 2019 compared to 2014 in Benha University Hospitals. This vast reduction between the two years might be as a result of continuous work during the five years from 2014 to 2019 including the continuous cleaning operations and application of the strategies of cockroaches control programs.

\section{FUNDING SOURCE DISCLOSURE}

This research received no financial support from any funding agency.

\section{CONFLICT OF INTEREST}

The authors declare that there is no conflict of interest.

\section{ACKNOWLEDGMENTS}

The authors are grateful to the administrative staff, heads of departments, and medical insect control team at Benha University Hospitals for facilitating to conduct this study.

\section{REFERENCES}

[1] Nasirian, H. (2019). Recent cockroach bacterial contamination trend in the human dwelling environments: a systematic review and meta-analysis. BJMS, 18(3): 540-545.

[2] Kutrup, B. (2003). Cockroach infestation in some hospitals in Trabzon, Turkey. Turk J Zool, 27: 73-77.

[3] Shiff, C. (1998). Vector control: methods for use by individuals and communities. Parasitol Today, 14(11): 470 (DOI: 10.1016/s0169-4758(98) 01304-0).

[4] Kawther, I. A.; Abdalmagid, M. A.; Elnaeim, I. A. et al. (2013). Toxicity 
of permethrin $25 \% \mathrm{EC}$ and diazinon 60\% EC insecticides against American cockroach Periplaneta americana (Linnaeus) at Omdurman locality hospitals, Khartoum State, Sudan 2012. Sudan J Public Health, 8(3): 113-118.

[5] Memona, H.; Manzoor, F. and Riaz, S. (2017). Species diversity and distributional pattern of cockroaches in Lahore, Pakistan. J Arthropod-Borne Dis, 11(2), 249-259.

[6] Brenner, B. L.; Markowitz, S.; Rivera, M. et al. (2003). Integrated pest management in an urban community: a successful partnership for prevention. Environ Health Perspect, 111(13): 1649-1653.

[7] Vythilingam, I.; Jeffery, J.; Oothuman, P. et al. (1997). Cockroaches from urban human dwellings: isolation of bacterial pathogens and control. Southeast Asian J Trop Med Public Health, 28: 218-222.

[8] Kongpanichkul, A.; Vichyanond, P. and Tuchinda, M. (1997). Allergen skin test re-activities among asthmatic Thai children. J Med Assoc Thai, 80(2): 69-75.

[9] Ash, N. and Greenberg, B. (1980). Vector potential of the German cockroach (Dictyoptera: Blattelidae) in dissemination of Salmonella enteritidis serotype Typhimurium. J Med Entomol, 17(5): 417-423.

[10] Fotedar, R.; Shriniwas, U. B. and Verma, A. (1991). Cockroaches (Blattella germanica) as carriers of microorganisms of medical importance in hospitals. Epidemiol Infect, 107: 181-187.

[11] Bell, W. J.; Roth, L. M. and Nalepa, C. A. (2007). Cockroaches: ecology, behavior, and natural history. JHU Press, Baltimore, MD, USA.

[12] Cochran, D. G. and World Health Organization (1999). Cockroaches: their biology, distribution and control (No. WHO/CDS/CPC/ WHOPES/99.3). World Health
Organization (https://apps.who.int/iris/ handle/10665/65846).

[13] Vahabi, A.; Shemshad, K.; Mohammadi, P. et al. (2011). Microbiological study of domestic cockroaches in human dwelling localities. Afr J Microbiol Res, 5(31): 5790-5792.

[14] Salehzadeh, A.; Tavacol, P. and Mahjub, H. (2007). Bacterial, fungal and parasitic contamination of cockroaches in public health of Hamadan, Iran. J Vector Borne Dis, 44(2): 105-110.

[15] Mahmoud, M. F.; El-Bahrawy, A. F.; El-Sharabasy, H. M. et al. (2013). Ecological investigation, density, infestation rate and control strategy of German cockroach, Blattella germanica (L.) in two hospitals in Ismailia, Egypt. Arthropods, 2(4): 216224.

[16] Dong-Kyu, L. (1995). Distribution and seasonal abundance of cockroaches (Blattellidae and Blattidae, Blattaria) in urban general hospital. Korean $\mathbf{J}$ Entomol, 25: 57-67.

[17] El-Sharabasy, H. M.; Mahmoud, M. F.; El-Bahrawy, A. F. et al. (2014). Food preference of the German cockroach, Blattella germanica (L.) (Dictyoptera: Blattellidae). Cercetări Agronomice în Moldova, XLVII: 8188.

[18] Yilmaz, A.; Tuncer, A.; Sekerel, B. E. et al. (2004). Cockroach allergy in a group of Turkish children with respiratory allergies. Turk J Pediatr, 46(4): 344-349.

[19] Kwon, T.-S. and Chon, T.-S. (1991). Population dynamics of the German cockroach, $B$. germanica in Pusan: I. Seasonal abundance and density change in habitats. Korean J Entomol, 21(3): 97-106.

[20] Lane, R. P. and Crosskey, R. W. (1993). Medical Insects and Arachnids. Chapman and Hall, London, NY, USA.

[21] Runstrom, E. S. and Bennet, G. W. (1990). Distribution and movement 
patterns of German cockroaches (Dictyoptera: Blattellidae) within apartment building. J Med Entomol, 27(4): 515-518.

[22] Chompoosri, J., Thavara, U., Tawatsin, A., et al. (2004). Cockroach surveys in the northern region of Thailand and Guangxi Province of China. Southeast Asian J Trop Med Public Health, 35: 46-49.

[23] Nasirian, H. (2017). Infestation of cockroaches (Insecta: Blattaria) in the human dwelling environments: a systematic review and meta-analysis. Acta Trop, 167: 86-98.

[24] Tee, H.-S.; Saad, A. R. and Lee, C.-Y. (2011). Population ecology and movement of the American cockroach (Dictyoptera: Blattidae) in sewers. J Med Entomol, 48(4): 797-805.

[25] Beccaloni, G. W. (2014). Cockroach Species File Online. Version 5.0/5.0. World Wide Web electronic publication (http://Cockroach.Species File.org).

[26] Brenner, R. J. and Pierce, R. R. (1991). Seasonality of peridomestic cockroaches (Blattoidea: Blattidae): mobility, winter reduction, and effects of traps and baits. J Econ Entomol, 84(6): 1735-1745.
[27] Bradt, D. L., Hoback, W. W. and Kard, B. M. (2018). American cockroach response to cold temperatures. Southwest Entomol, 43(2): 335-342.

[28] Haghi, F. M.; Nikookar, H.; Hajati, H. et al. (2014). Evaluation of bacterial infection and antibiotic susceptibility of the bacteria isolated from cockroaches in educational hospitals of Mazandaran University of medical sciences. Bull Env Pharmacol Life Sci, 3: 25-28.

[29] Baumholtz, M. A.; Parish, L. C.; Witkowski, J. A. et al. (1997). The medical importance of cockroaches. Int J Dermatol, 36(2): 90-96.

[30] Valles, S. M. and Yu, S. J. (1996). Detection and biochemical characterization of insecticide resistance in the German cockroach (Dictyoptera: Blattellidae). J Econ Entomol, 89(1): 21-26.

[31] Pridgeon, J. W.; Appel, A. G.; Moar, W. J. et al. (2002). Variability of resistance mechanisms in pyrethroid resistant German cockroaches (Dictyoptera: Blattellidae). Pestic Biochem Physiol, 73(3): 149156.

\section{How to cite this article:}

Baz, M. M. and Hegazy, M. M. (2021). Reduction of cockroach density and spreading in Benha University Hospitals (Egypt) in the year 2019 compared with the year 2014. Egyptian Journal of Zoology, 75: 39-47 (DOI: 10.12816/ejz.2021.54858.1047). 


\section{الحد من كثافة الصر اصير وانتثار ها في مستثفيات جامعة بنها (مصر) فئمار \\ في عام 2019 مقارنة بعام 2014}

\section{محمد محمود باز 1، مايسة محمد حجازي 1 و 2.}

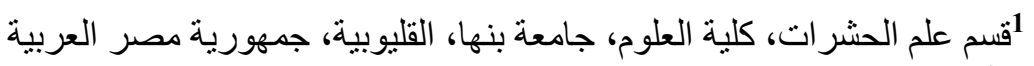

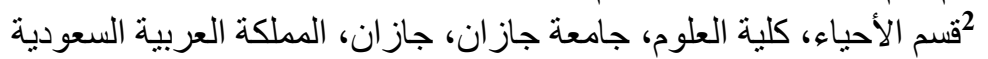

تسبب الصر اصير مشاكل صحية عامة مرتبطة بالنفايات البشرية ومسبيات الأمر اض. وفي الدر اسة الحالية تم تقييم توزيع

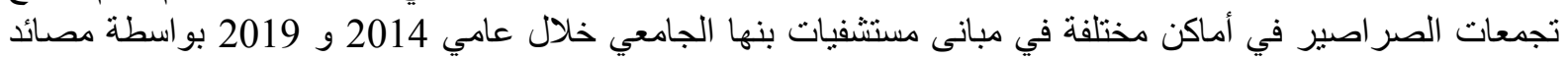

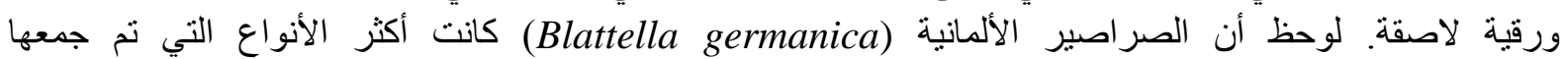

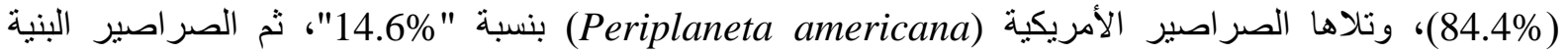
(Periplaneta brunnea)

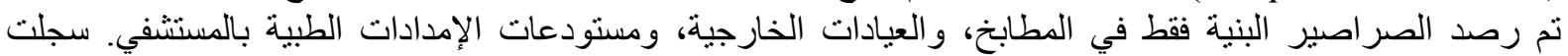

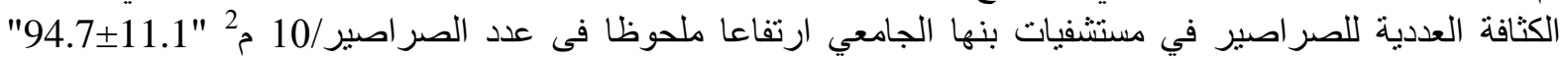

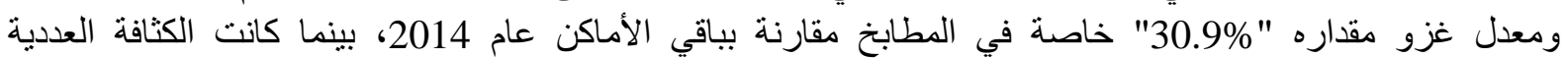

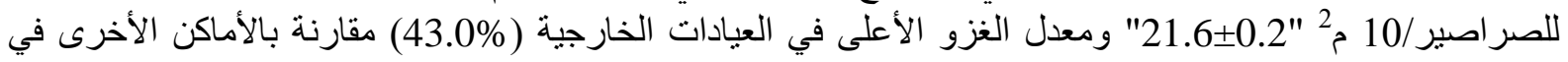

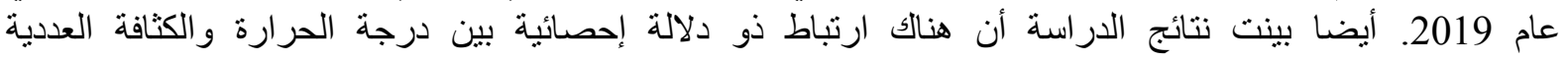

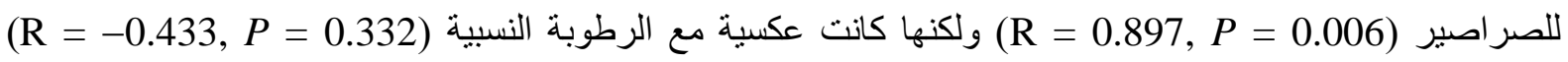

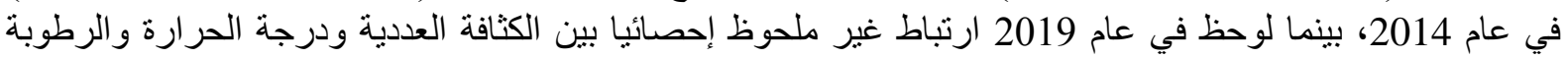

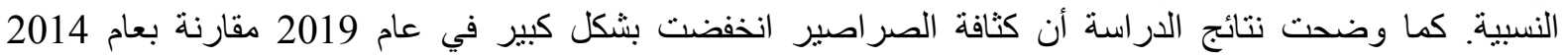

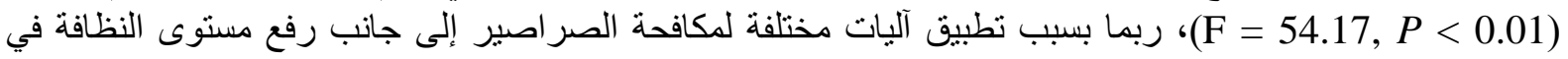

